Volume III Issue III May

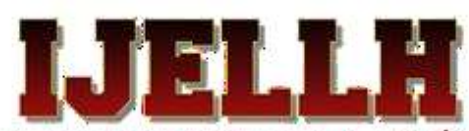

International Journal of English

2015- ISSN 2321-7065

Language, Literature and Humanities

\title{
Impact of Social Media on English Language: A Review
}

\author{
Dr. Neha Sharma \\ Assistant Professor in English \\ Saraswati Mahila Mahavidhalaya \\ Palwal (Haryana) India \\ nehashrma77@gmail.com
}

Language being a potent vehicle of transmitting cultural values, norms and beliefs remains a central factor in determining the status of any nation. India is a multilingual country which tends to encourage people to use English at national and international level. Basically English in India owes its presence to the British but its subsequent rise is not fully attributable to the British. It has now become the language of wider communication which is now spoken by large number of people all over the world. It is influenced by many factors such as class, society, developments in science and technology etc. However the major influence on English language is and has been the media. Media has always played a major role in influencing language from the very first manuscript to the use of internet language in the modern era. In fact, globalization and development in modern technology have enhanced the learning process. As globalization has made the world smaller. The media relates to all modes of transmission from internet, radio, television, video, audio and any other sources that has the ability to transmit information. Diversity of media is now used as a fundamental teaching aid, not only in the rudiments of English within the National Curriculum, but as an essential requirement to meet the challenges of the global market. No body can ignore the importance of this global language which provides the basis for survival these days. The scope of media, specially internet is indeed very high. Today one can GOOGLE out any thing and everything he desires. Innumerable social networking sites are popping - up every day. Orkut, Linked in, Zorpia, Hi-5, Facebook and Twitter are only to name a few. The vital role of media in the learning process of English language has been observed very well by a critic who states: 
"Learning from media and technology is often referred to in terms such as instructional television, computer based instruction or integrated learning system."

Thus ever since media came into existence, it has played a pivotal role in moulding and forming the thought process and lingua franca of all who came under its spell. Social media has spawned new words and morphed old ones. English newspapers are quite popular in India, both in terms of the number of periodicals and the numbers of copies printed. Most of the major national newspapers are published in English and are popular in cities and towns.

Further as news medium radio remains a state monopoly in India from time to time, assertions are made that FM radio is poised for an exponential growth in India. There are around $250 \mathrm{FM}$ radio stations broadcasting now and in the next phase, 1100 more are expected to be licensed, most of them are private.

These channels broadcast many programmes in English and regional languages. Sport commentaries, which have large audience, are delivered in English, Hindi, and in some regional languages. News casters, specially on AIR and Doordarshan, try to maintain an accent close to British Received Pronunciation. Until about a decade ago, the diction of the newscasters on AIR was regarded as a model for pronunciation.

Similarly CNN, BBC and some other international channels have proved to be very popular with urban audiences. Watching Television is an all time favorite hobby of children, youngsters as well as the elderly people. It affects the life style and behavior of people to a great extent. Now a days, these T.V. people are supporting a new language which is known as Hinglish. It is a mixture of Hindi and English. Hinglish is the most popular language of T.V. advertisements.

„Hungry Kya? „Yeh Dil Mange More“, „What your Bahana Is?”e etc. are some of the Hinglish campaigning advertisements.

The turning point, to deteriorate the language was the introduction of cable T.V. in mid-1990s, as noted by cultural observers. Earlier it was Delhi Doordarshan, broadcasting Hindi and English news bulletins separately, beside other programmes. Hinglish gained much currency with the emergence of various channels presenting various types of programms. 
Now a days Hinglish titles of the movies are gaining much popularity. Take for instance : Jab We Met, Bheja Fry, Tanu Weds Manu, Ishq Wala Love, Mere Brother ki Dulhan, Me or Hum etc. Such titles are applauded because they are different from early titles, and at the same time they present a fusion, which is the main feature of this modern era.

With the advent of quicker and more vivid communication channels via social media and social technologies, English has been deteriorated incredibly enough. Yet there is another aspect of it,

"English language can adapt swiftly and easily unlike any

other language in the world"

(Crough)

Further films/movies offer the full range of language from colloquial to literary, unaffected to flowery, lending ample opportunities to learners to experience power of language for communication. Narrative films specially make use of language to advance plot, define characters, and establish mood. Watching films particularly help in improving listening comprehension and enhance vocabulary. Subtitles and closed captioning can help students increase reading speed. Thus films can also be effectively used for developing writing and oral presentation skills. In the same line, films can be used as rich teaching resource for various other important skills such as speaking, repeating dialogues, dramatic enactments of scenes, script and dialogue writing.

To conclude Media has profound impact on education. It is the power of media that one headline either in praise or against a particular thing can change the entire scenario in just one stroke. Therefore if we relate this powerful tool with the education of today, we will find that it works as a great tool in inspecting and grading in school as well as in universities. Moreover in the present scenario students and their parents feel the convenience of mass Media. Nine-in-ten family homes with children use internet and keep on searching all the aspects of learning using it. Thus media helps them to save their time as well as provide them all the information at their disposal. In short, the impact of media on people, language and education is very much in the positive and progressive direction. 


\section{IJELLH \\ International Journal of English \\ Language, Literature and Humanities}

2015- ISSN 2321-7065

\section{References}

1. Crouch, Giles. "The Impact of Social Media on English". http://www.mediabadger.com/ 2011/01/ the - impact of social media on English language / \# sthash/\#slash.313 DZKXY.dpuf.

2. http:/1 grammar.about.com / od/ph/g/hinglish.ht

3. Bagdikian, Ben H. (1997), The Media Monopoly fifth Edition (Boston: Beacon, (Press).

4. Venkataramiah, E.S. (1987), Freedom of Press: Some recent trends (Delhi: B.R. Publishing Corporation.)

5. Edward, John (1985) Language, Society and Identify. Oxford: Basil Blackwell.

6. Graddol David (1997). The future of English. The British Council. 